DOI: $10.17516 / 1997-1370-0560$

УДК 81’25:316.642.3

\title{
Interactivity of Simultaneous Interpreters as Actors of a Cognitive Event
}

\author{
Elena V. Chistova \\ Siberian Federal University \\ Krasnoyarsk, Russian Federation
}

Received 20.01.2020, received in revised form 01.02.2020, accepted 04.03.2020

\begin{abstract}
The paper refers to studying interactivity models of simultaneous interpreters in the field. It describes the process of simultaneous interpretation as a cognitive event considering two participants in the context of cognitive dissonance and problem solving. The key concept of identifying the models is empathy to a booth mate which has never been studied in the context of Cognitive Translation Theory before. The results of Cognitive Event Analysis show four main interactivity models: empathic productive, empathic unproductive, empathic destructive and no empathic. The examples of empathic productive interactivity model demonstrate both material, verbal and cognitive empathy. The trajectories of giving a hint show three obligatory cycles of creating productive empathy: identifying cognitive dissonance, illustrating emphatic behavior and inviting to interactivity. The most precious hint happens when deep cognitive empathy between the partners can encourage them by embodied help without any verbal or material hints. It includes two additional cycles: mutual cognitive dissonance and individual attempt to solve the problem. This model is observed mainly in pairs of highly qualified interpreters with enough experience of coupling. Novice simultaneous interpreters are not able to show empathy, so tutors should train the skill of overcoming this gap. Empathic unproductive or destructive interactivity models are observed in pairs of highly qualified interpreters with no experience of coupling because of incongruent mental processes of subject and object.
\end{abstract}

Keywords: cognitive linguistics, translation studies, distributed cognition, translation event, cognition, communication, empathy.

Research area: language theory.

Citation: Chistova, E.V. (2020). Interactivity of simultaneous interpreters as actors of a cognitive event. J. Sib. Fed. Univ. Humanit. Soc. Sci., 13(3), 375-384. DOI: 10.17516/1997-1370-0560.

(C) Siberian Federal University. All rights reserved

* Corresponding author E-mail address: echistova@sfu-kras.ru ORCID: 0000-0002-4016-7935 


\section{Introduction}

During the long history of theory and practice of translation, scholars have been trying to study the process of making translation decisions, to find out the factors contributing to the search for the most effective solutions, and to explain the nature of cognitive processes occurring in the mind of an interpreter at the moment of decision making. The study of the "black box" of simultaneous interpreters seems to be the most interesting from the perspective of cognitive translation studies, since it is referred to as "the extreme type of cognitive processes" (Hervais-Adelman, Moser-Mercer, Golestani, 2015; Konina, Chernigovskaya, 2018: 178 ) and the most difficult type of translation from the perspective of methodology and cognitive abilities.

\section{Theoretical Framework}

It is difficult, and sometimes impossible, to explain the interpreters' mental processes when perceiving them as a cognitive living system by considering linguistic factors only.

There is a significant number of works devoted to the study of the cognitive mechanism of simultaneous interpretation (Gerver, 1976; Daro, Fabbro, 1994; Gile, 1991), designing cognitive models of simultaneous interpretation (Gile, 1999; Paradis, 1994; Seeber, Kerzel, 2012), description of cognitive skills required to perform simultaneous interpretation (for example, working memory - (Padilla et al., 1995; Shlesinger, 2003); cognitive control - (Riccardi et al., 1998; Strobach et al., 2015); cognitive flexibility - (Yudes et al., 2011); stress resistance (Kurz, 1997; Cooper et al., 1982), etc.

When scholars explore the interpreters' working results without considering the environment, it leads to the wrong way of understanding the process. For example, the phrase "poor-quality interpretation" in the textual context could only seem to be the "good job" considering the complicated circumstances that the interpreter was in at that time. Thus, studying the interpreters' cognition in the field (Risku et al., 2017) and considering all the things around could be a more productive way of.

In existing studies on simultaneous interpretation, scholars tend to focus on one inter- preter trying to acquire and improve linguistic and cognitive skills as well as algorithms for making translation decisions. However, in global practice interpreters, as a rule, work in pairs and we should also study their activities in collaboration. Thus, the purpose of the paper is to describe interactivity of simultaneous interpreters as actors of a cognitive event in the field. From this perspective, it is interesting and important to study the process as a translation event which includes situations happening to the interpreters during their work in the booth.

Interactivity means "sense-saturated coordination that contributes to human action" (Steffensen, 2013: 212). We engage in sense-making as our bodies integrate present circumstances with autobiographic memories and sociocultural histories: the not-here and the not-now saturate our here-and-now coordination via sense-making. The concept of 'human interactivity' grounds anti-disciplinary (pace Peter Jones) empirical work that attempts to move beyond the microsocial study of social interaction, beyond the cognitive study of functional, computational systems and minds, and beyond the study of biological organisms sui generis. It presupposes a crucial distinction between 'interaction' and 'interactivity'; interaction captures relation of dependence between separable systems, whereas interactivity explores their bidirectional coupling.

\section{Methods}

We describe interactivity of simultaneous interpreters by using cognitive event analysis introduced by Sune Steffensen in 2013. It studies cognitive ecosystems via a microscopic focus on the bodily and inter-bodily dynamics of gesture, prosody, movements, etc. It has been both applied to naturalistic and experimental data. The analysis focuses on cognitive ecosystems by investigating the system's cognitive trajectory, that is, the dynamical and nonlinear path that the system creates as it achieves a given cognitive result. It particularly focuses on phase transitions along this trajectory (Steffensen et al., 2016).

Cognitive event analysis is a way of approaching the interactivity of problem-solving. Thus, the study of simultaneous interpretation 
as a cognitive event is, in our opinion, the most promising and forward-looking. Simultaneous interpreters should be perceived as a living cognitive system that can demonstrate an approach to solving problems in field based on the principle of interactivity.

The material for the analysis includes video recordings of simultaneous interpretation that we managed to shoot during real-life sport events (head of delegation's meetings, team captains' meetings, press conferences, etc.). The participants are presented by highly qualified interpreters with no experience of coupling with each other before and experienced interpreters with more than 100 hours of working together. They were informed about the video camera but they did not know the exact purpose of the research. They thought it was both for the experimental data and for their protection in case of complaints about the quality of service or controversial situations on the venue. The interpreters tried to predict the details of future interpretation getting as much information as possible. They did not pay attention to the video camera because they were interpreting at an important event. They felt relaxed during the recording because they sometimes used inappropriate vocabulary during setting up and breaks to express their real emotions.

The material also includes the videos of students who were filmed during their practice classes at the School of Interpretation after 3 months of their training. They were also informed about the video camera. They thought it was both working as a control tool for self-assessment and for getting the experimental data.
They did not know the details of the future analysis.

The videos of interpreters' cognitive interaction last 8 hours 13 minutes. Table 1 summarizes the details about the video timing and characteristics of interpreters.

Apart from cognitive event analysis, we also use the method of observation made by the researcher because some interpreters refuse either to be filmed or to give permission to make these recordings public. The work also involves the method of interviewing interpreters, as the real situation is not always clear from the video. The camera shoots interpreters in the booth, but the speakers can only be heard via recording. Accordingly, it is not always possible to synchronize the events correctly to match the audio and video recordings made on different media. In this case the interview helps to restore events, make adjustments, and clarify the important points from the agents of a cognitive event.

\section{Results: empathic productive interactivity model}

The first model identified via cognitive event analysis is called "empathic productive interactivity". We decided to call it this way because it demonstrates the way interpreters may be helpful to each other, the way they may predict the difficulties during the work of a partner and influence them to improve the situation (Chmiel, 2008). The crucial point here is to achieve the result which means to choose the most effective way of encouraging and make the partner "save" the translation. Being empathic in this case is considered as

Table 1. Research corpus characteristics

\begin{tabular}{|c|c|c|}
\hline Video No. & Video Length (min) & Interpreters' Characteristics \\
\hline 1 & 42 & novice simultaneous interpreters \\
\hline 2 & 54 & novice simultaneous interpreters \\
\hline 3 & 161 & experienced interpreters with 5 years of coupling \\
\hline 4 & 31 & highly qualified interpreters with no experience of coupling \\
\hline 5 & 72 & highly qualified interpreters with no experience of coupling \\
\hline 6 & 91 & highly qualified interpreters with no experience of coupling \\
\hline 7 & 37 &
\end{tabular}


being able to predict the partners' cognitive dissonance, to feel sympathetic to the situation and solve the problem quickly and productively. Thus, empathic productive interactivity model includes the following actions: interpreters help to switch the channel with different languages on the equipment, turn over the presentation pages, write down the numbers, suggest or correct the terms, sometimes help to remember or use the right word using gestures and symbols.

Here is an example of empathic productive interactivity. In the episode of video recording (Fig. 1) we can see the same couple of experienced interpreters with 5 years of working together (White and Grey). The case shows a problem with terminology, since the materials were not provided for the interpreters in time. First of all, Grey couldn't understand a short form of the term "proximity card", because of vague speech of the orator who has shortened the term in her own style like "proxycard" (the unusual written form used in the presentation). Grey interprets from English into Russian. There is a translation text:

- Если это главы ... делегаций, то вам нужна будет ... Что такое проксикарс? ... то вам нужна будет ... с проксикарами... вам нужно подавать заявку... и нужно ... предоставлять проксикарту. Что касается спортивных.... [If these are heads of ... delegations, then you will need ... What are "proxicars"? ... then you will need ... with proxicars ... you need to apply ... and you need ... to provide a proxicard. As for sports ...].

In the Fig. 1, we can see Grey interpreting and White sitting right next to her. There is no interaction between the partners, but the off-mike interpreter in White is engaged in the process by concentrating as she is holding hands together in a closed position on the table and looking at the screen with the orator. Having listened to the first hesitations of Grey and noticed her puzzled face in Fig. 1b, White starts to monitor the presentation. Feeling frustrated about her interpretation, Grey decides to ask for help in Fig. 1c. She presses the Mute button and quickly asks: "What are "proxicars"?" In Fig. 1d White shakes her head indicating that she does not know the term either. In the next Fig. having got no verbal hint Grey tries to guess what the speaker means. While her partner goes on seeking for the right translation Grey finds the term relevant to the context.

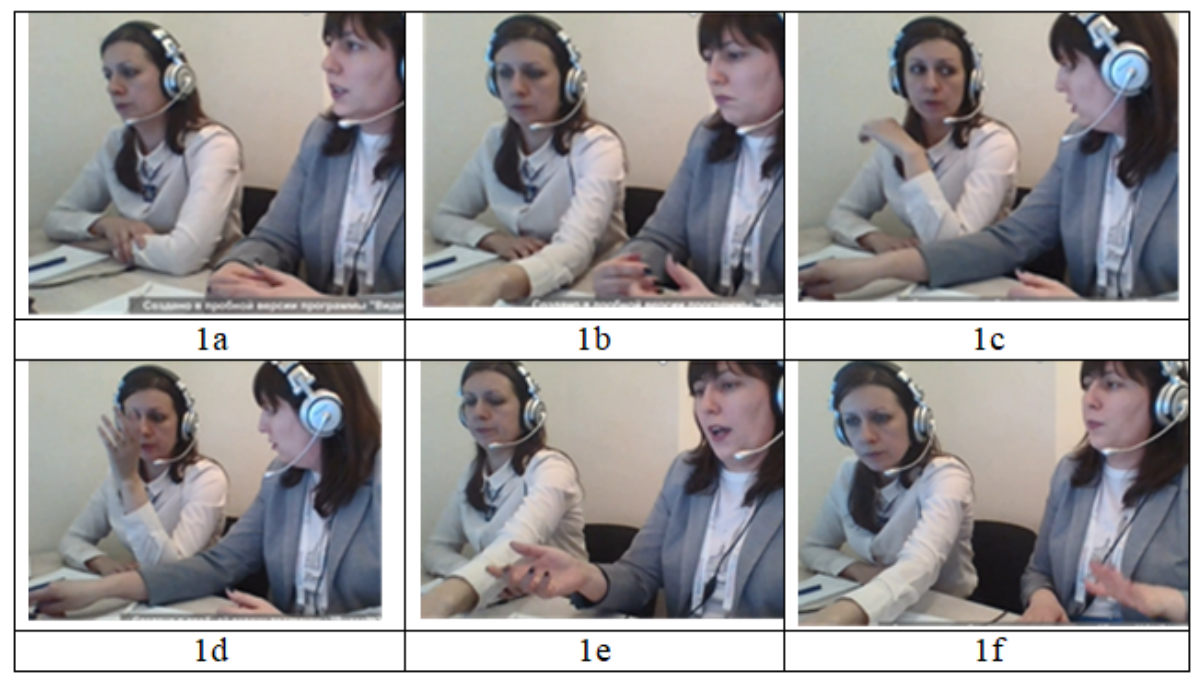

Fig. 1. No hint is good hint. $1 \mathrm{a}(03,84)$ : Grey is interpreting, White is observing the situation. $1 \mathrm{~b}$ $(08,05)$ : Grey looks puzzled, White tries to find necessary information in the presentation that they can see on their screen in the left corner of the table. 1c $(11,02)$ : Grey presses the Mute button to ask White for a hint. 1d (11,68): White shows that she doesn't know the concept the speaker is talking about. 1e (13,06): Grey continues interpreting, White goes on seeking for the term in the presentation. If $(17,63)$ : Grey manages to find the adequate term without any verbal hint 
According to computerized timing (Fig. 2), the episode is divided into 6 cycles. The first cycle demonstrates individual work of the partners with no interactivity. The second cycle changes the situation as White manages to identify Grey's cognitive dissonance by hesitation, gestures and mimics. White immediately turns to Grey and stretches out her hand both searching for the information in the laptop and getting closer to the partner. This gesture makes Grey feel her partner's empathy as she decides to ask her for the verbal hint. But during the fourth cycle they both understand mutual cognitive dissonance. White lifts her hand in dismay and nods her head slightly pronouncing some strange sounds without any words. This is an event point, as we think, because it is a transition cycle which makes Grey change the strategy. Having understood that something is wrong with the pronunciation of the term Grey starts to choose the most notion via context. During the fifth cycle we can see her gesturing a lot that means a sort of brainstorming work in solving the problem. Meanwhile, her partner is always looking for something in the laptop with her hand stretched Grey. In about 4 second Grey leans her back to the chair and creates a gesture like putting the dot in a sentence. In the very moment she corrects her interpretation having guessed what term is used by the orator.

This example shows deep cognitive empathy between the partners when they can encourage each other by embodied help without any verbal or material hints. In my opinion, White's lifting hand in dismay is like a bifurcation point that changes the general mental trajectory.

\section{Results: empathic unproductive interactivity model}

The next model we manage to identify via video recordings is an empathic unproductive interactivity model. We call it "unproductive" because there is no expected result in the end. The partners feel empathic and try to help each other but they cannot choose the most effective way of doing it. Why does it happen? The roots of the problem can be found in the phenomenon of empathy.

According to our research corpus we manage to find two reasons of incongruent behavior in the context of the model. First, it is caused by the lack of either interpreter's experience on the whole or no experience of coupling (incongruent mental processes of subject and object) because an interpreter can only demonstrate primitive emotional identity but cannot accomplish a desired action. In other words, they are not capable of feeling the partner as deep as the situation demands. Thus, the model includes the following actions: the interpreter gives a hint when a partner is in the headphones (Fig. 3a) or writes a hint far from the partner's gaze (Fig. 3b), for example. However, the last but not the least example may be presented in the discharge of an empathic destructive interactivity model (see below), when the passive interpreter begins to write something in his/her notepad, thereby diverting the active interpreter who continues to work just realizing that it does not matter at the moment.

Pedagogical training might be another reason for such behavior. This happens when, for example, a passive interpreter writes down a hint, closing it with a hand (Fig. 3c). It happens

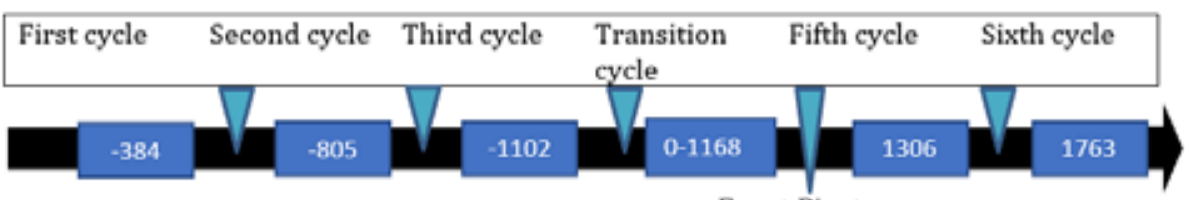

Event Pivot

\begin{tabular}{|l|l|l|l|l|l|}
\hline $\begin{array}{l}\text { Interpretation } \\
\text { process }\end{array}$ & $\begin{array}{l}\text { Identifying } \\
\text { cognitive } \\
\text { dissonance }\end{array}$ & $\begin{array}{l}\text { Illustrating } \\
\text { empathic } \\
\text { behavior }\end{array}$ & $\begin{array}{l}\text { Illustrating } \\
\text { mutual } \\
\text { cognitive } \\
\text { dissonance }\end{array}$ & $\begin{array}{l}\text { Individual } \\
\text { attempt to } \\
\text { solve achieving } \\
\text { problem a }\end{array}$ & $\begin{array}{l}\text { acitive } \\
\text { positi } \\
\text { result }\end{array}$ \\
\hline
\end{tabular}

Fig. 2. The trajectory of Spotted's giving material hints (from -256 to +2913 ). The figure shows four stages that the DCS undergoes as Spotted manages to give a hint 


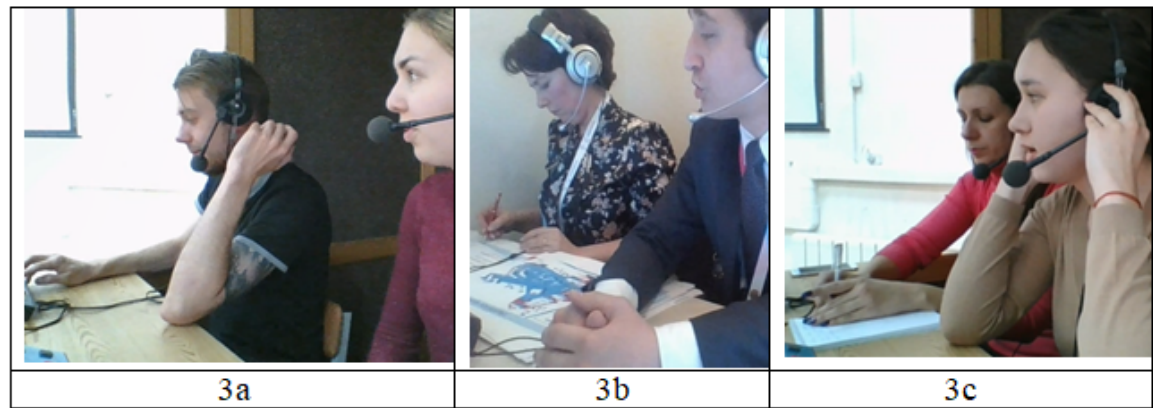

Fig. 3. Examples of empathic unproductive interactivity model

if the partner has noticed a communicatively insignificant error at the moment which can be mentioned after the session of simultaneous interpretation as it will not affect the outcome of events.

\section{Results: empathic destructive interactivity model}

The next model is called as "empathic destructive interactivity model". If one distracts the active interpreter with additional channel of information, it might not be productive but might, for sure, be destructive. For example, the video shows a case when the supervisor from the audience demanded an urgent correction of a mistake in terminology (Fig. 4a), so the conference manager had to show the correct version on her phone. However, the attempt failed (Fig. 4d) and the interpreter barely managed to restore the process of interpretation (Fig. 4e). As recent studies show, multitasking splits our brain because it can simultaneously perform only two tasks. At this time, two hemispheres of the human brain are involved in work. Thus, people being around the active simultaneous interpreter should take this fact into consideration.

This model can also be traced when the passive interpreter pushes the active one to indicate an error (Fig. 4f). At the same time,

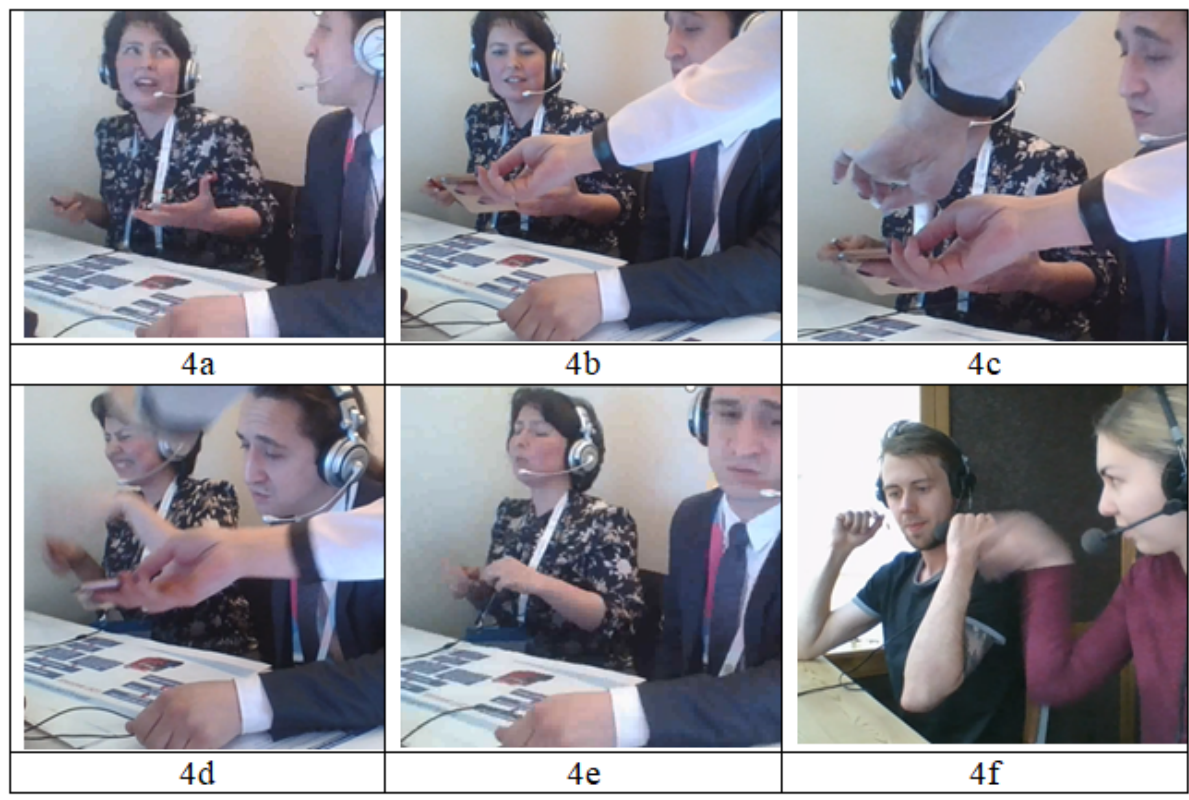

Fig. 4. Examples of empathic destructive interactivity model 
there is no hint, but only the fact of an error is mentioned. Such behavior is also considered to be destructive.

\section{Results: nonempathic interactivity model}

A nonempathic model includes such actions as: partners are not looking at each other (Fig. 5 (11a, d)), behaving indifferently (Fig. 5 (11b)), texting on the phone (Fig. 5 (11f)), taking pictures (Fig. 5 (11c)), etc. On the one hand, this may be demonstration of relaxing after exhausting interpretation, but only in the case of a long-term process during the day. In our case, the interpreters worked for several hours with long intervals, so most likely this behavior relates to non-empathy.

There are also cases of non-interactivity. If there are interpreters of the same gender in the booth, it is difficult for the listeners to understand by their voices who is interpreting at a moment. In case of bad interpretation of one of the interpreters, the good partner prefers to get out of the booth, so that the listeners could understand that it is not him or her who interprets so badly.

\section{Conclusion}

The study by cognitive event analysis leads to the following conclusions:

1. Simultaneous interpretation is a cognitive event that requires empathic interactivity with a partner in a situation of cognitive dissonance in order to eliminate communicatively significant errors at the moment and ensure high-quality simultaneous interpretation.

2 . Productive interactivity is the most important characteristics of a simultaneous interpretation in addition to stress tolerance, efficiency and endurance.

3. According to the results of the study in the field, interactivity between partners appears in the situations of cognitive dissonance during the simultaneous interpretation. Interactivity is caused by empathic attitude to the partners and needs more detailed research

4. The trajectories of giving a hint in the empathic productive interactivity model show three obligatory cycles of creating productive empathy: identifying cognitive dissonance, illustrating emphatic behavior and inviting to interactivity. These cycles are enough to pro-
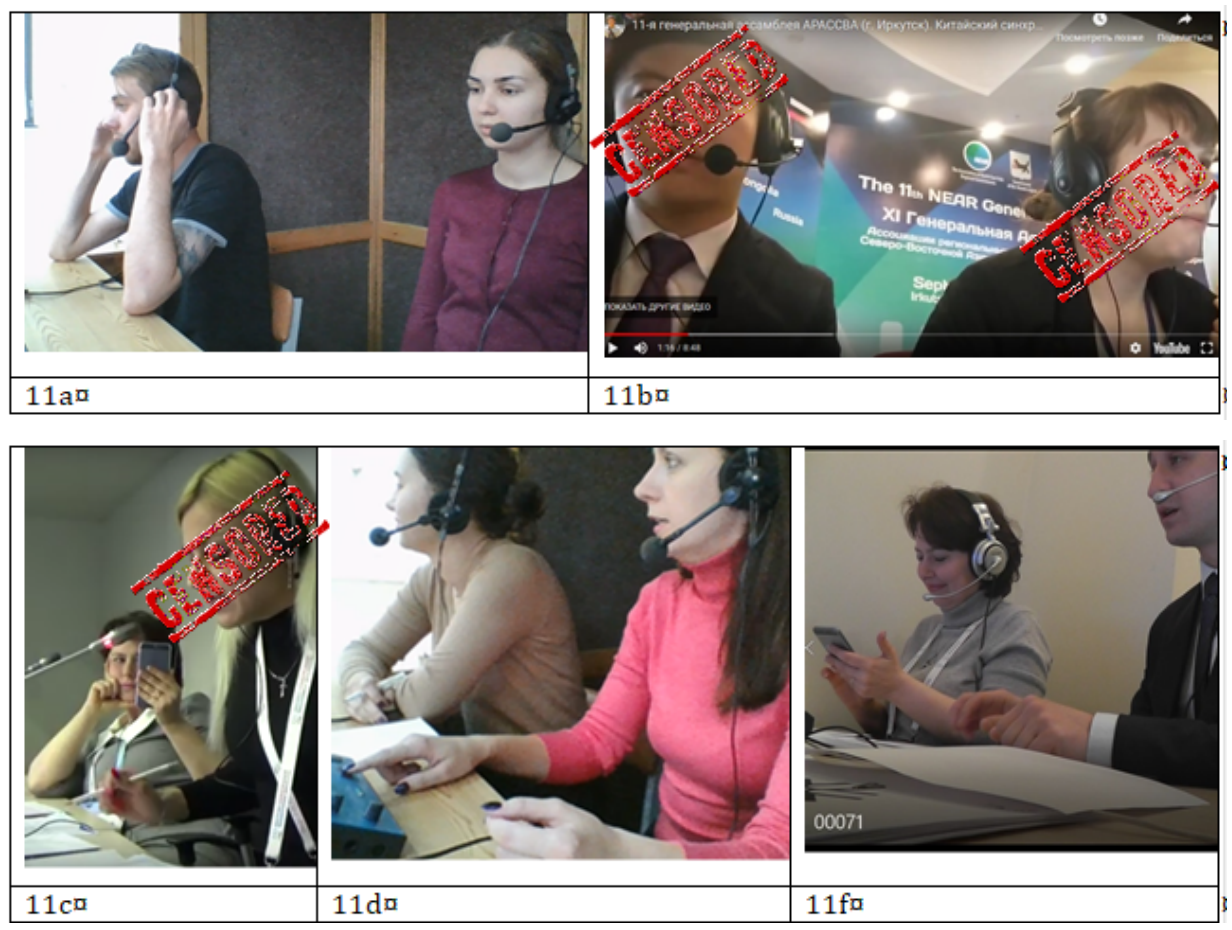

Fig. 5. Examples of nonempathic interactivity model 
vide verbal hint only. In case of material hint it is necessary to include mutual cognitive dissonance. The most precious hint happens when deep cognitive empathy between the partners can encourage them by embodied help without any verbal or material hints but including 2 additional cycles: mutual cognitive dissonance and individual attempt to solve the problem.

5. An empathic productive interactivity model is observed mainly in the pairs of experienced interpreters. Novice simultaneous interpreters, as the analysis has shown, are not able to provide empathy - tutors need to specifically draw their attention to this gap and teach them.

6. The empathic unproductive and destructive interactivity models are more common among highly qualified interpreters with no experience of coupling and novice simultaneous interpreters.

7. The nonempathic interactivity model is more common among novice simultaneous interpreters and can be an indicator of a non-professional.

\section{References}

Chmiel, A. (2008). Boothmates Forever? - on Teamwork in A Simultaneous Interpreting Booth. In Across Languages and Cultures, 9(2), 261-276. DOI: 10.1556/Acr.9.2008.2.6, available at: http://www.akademiai.com/content/b512262w457x1210/?p=2ef008acd8774ealb0a44cf0df68f970\&pi=5

Cooper, C.L., Davies, R., Tung, R.L. (1982). Interpreting stress: Sources of job stress among conference interpreter, In Multilingua-Journal of Cross-Cultural and Interlanguage Communication, 1(2), 97-108.

Daro, V., \& Fabbro, F. (1994). Verbal memory during simultaneous interpretation: Effects of phonological interference. In Applied Linguistics, 15(4), 365-381.

Gerver, D. (1976). Empirical studies of simultaneous interpretation: A review and a model. In R. Brislin (Ed.). Translation. Applications and Research. New York: Gardner Press, 1976.

Gile, D. (1991). Methodological aspects of interpretation (and translation) research. Target. In International Journal of Translation Studies, 3(2), 153-174.

Gile, D. (1999). Testing the Effort Models' tightrope hypothesis in simultaneous interpreting-A contribution. In HERMES-Journal of Language and Communication in Business, 12(23), 153-172.

Hervais-Adelman, A., Moser-Mercer, B., Golestani, N. (2015). Brain functional plasticity associated with the emergence of expertise in extreme language control. In NeuroImage, 114, 264-274.

Konina, A.A., Chernigovskaya, T.V. (2018). Sinhronnyj perevod kak jekstremal'nyj vid kognitivnyh processov (obzor jeksperimental'nyh issledovanij) [Simultaneous interpreting as an extreme type of cognitive processes (review of experimental studies)]. Moscow. In Voprosy psiholingvistiki [Psycholinguistic Issues], 4 (38). P. 178-204.

Kurz, I. (1997). Interpreters: stress and situation-dependent control of anxiety. In Transferre Necesse Est. Proceedings of the 2nd International Conference on Current Trends in Studies of Translation and Interpreting, 201-206.

Padilla, P., Bajo, M.T., Cañas, J.J. (1995). Cognitive Processes of Memory in Simultaneous Interpretation. In J. Tommola (Ed.). Topics in Interpreting Research, University of Turku Press, 61-71.

Paradis, M. (1994). Neurolinguistic Aspects of Implicit and Explicit Memory: Implications for Bilingualism and SLA. In N. Ellis (Ed.). Implicit and Explicit Language Learning, London, Academic Press, 393-419.

Riccardi, A., Marinuzzi, G., Zecchin, S. (1998). Interpretation and stress. In The Interpreters' Newsletter, 8, 93-106.

Risku, H., Rogl, R., Milosevic, J. (2017). Translation practice in the field. Current research on socio-cognitive processes. In Translation Spaces, 6 (1): 3-26. DOI: 10.1075/ts.6.1.01ris

Seeber, K.G., \& Kerzel, D. (2012). Cognitive load in simultaneous interpreting: Model meets data. In International Journal of Bilingualism, 16(2), 228-242.

Shlesinger, M. (2003). Effects of presentation rate on working memory in simultaneous interpreting. In The Interpreters' Newsletter, 12, 37-49. 
Steffensen, S.V. (2013). Human interactivity: problem-solving, solution-probing, and verbal patterns in the wild. In Cowley, S.J., Vallée-Tourangeau, F. (Eds.), Cognition Beyond the Body: Interactivity and Human Thinking, 195-221.

Steffensen, S.V., Vallée-Tourangeau, F., Vallée-Tourangeau, G. (2016). Cognitive events in a problem-solving task: a qualitative method for investigating interactivity in the 17 Animals problem. In Journal of Cognitive Psychology, 28: 1, 79-105.

Strobach, T., Becker, M., Schubert, T., Kühn, S. (2015). Better dual-task processing in simultaneous interpreters. In Frontiers in psychology, 6, 1590.

Yudes, C., Macizo, P., Bajo, T. (2011). The influence of expertise in simultaneous interpreting on non-verbal executive processes. In Frontiers in psychology, 2, 309. 


\title{
Модели взаимодействия синхронных переводчиков как акторов когнитивного события
}

\author{
E.В. Чистова \\ Сибирский федеральный университет \\ Российская Федерачия, Красноярск
}

\begin{abstract}
Аннотация. В статье рассматривается процесс синхронного перевода в контексте теории распределенного познания. Распределенный характер деятельности синхронных переводчиков подразумевает взаимообусловленность индивидов, языка, коммуникации, материальных объектов. Объектом анализа выступает взаимодействие переводчиков-синхронистов, работающих в «естественных» условиях - во время реального мероприятия с обеспечением синхронного перевода. Цель статьи - выявление моделей взаимодействия акторов в когнитивном процессе синхронного перевода. В работе впервые в переводоведении используется метод анализа когнитивного события в парах синхронистов: 1) высококвалифицированных специалистов с опытом совместной работы, 2) синхронистов, не переводивших ранее в одной кабине, 3) а также начинающих переводчиков. Границы одного когнитивного события определяются временным отрезком, направленным на решение определенной задачи, требующей от партнеров активного взаимодействия для формирования единой когнитивной системы распределенного характера. В качестве параметра идентификации моделей взаимодействия установлена категория эмпатии, впервые рассматриваемая в контексте когнитивного переводоведения. В результате исследования были выявлены четыре модели взаимодействия переводчиков-синхронистов: эмпатичная продуктивная, эмпатичная непродуктивная, эмпатичная деструктивная и неэмпатичная. Сделан вывод о том, что категория эмпатии сопряжена с профессионализмом переводчика, однако она актуализируется в поведении не всех представителей профессии или не всегда. Помимо вербальной и материальной помощи партнера по кабине, наиболее эффективной является его когнитивная поддержка, например, когда благодаря эмпатии взаимный когнитивный диссонанс, испытываемый обоими партнерами при решении определенной задачи, мотивирует переводчиков оказывать взаимовлияние посредством обмена когнитивными реакциями и оба профессионала таким образом становятся частью когнитивного опыта в ситуации «здесь и сейчас».
\end{abstract}

Ключевые слова: когнитивные науки, распределенное познание, когнитивный агент, когнитивное событие, когниция, коммуникация, эмпатия.

Научная специальность: 10.02.19 - теория языка. 